\title{
Notícia: Maria Amelia Matos (1939-2005): Generosidade, Competência, Liderança ${ }^{1}$
}

\author{
Gerson Yukio Tomanari ${ }^{2}$ \\ Universidade de São Paulo
}

\section{News: Maria Amelia Matos (1939-2005): Generosity, Competence, Leadership}

Consta oficialmente que Maria Amelia Matos nasceu na cidade de Birigüi, interior de São Paulo, em 14 de abril de 1939. Mas esse dado merece uma ressalva, pois ela nascera mesmo um dia depois. Aconteceu que o seu pai, quem a registrou, preferiu não ter três filhos com a mesma data de nascimento. Não por isso, certamente, mas é fato que Maria Amelia foi uma pessoa especialmente singular. No dia 17 de maio de 2005, com profundo pesar, recebemos a notícia do falecimento de Maria Amelia após um longo período em que lutou contra um câncer, permanentemente armada de serenidade, lucidez, esperança.

Maria Amelia deixou Birigüi e mudou-se para a cidade de São Paulo em dezembro de 1957, ano em que freqüientou um curso intensivo pré-vestibular para ingressar, no ano seguinte, na primeira turma do curso de Psicologia da Universidade de São Paulo. No último ano de sua graduação, exatamente em 1961, conheceu o professor Fred S. Keller quando ele esteve no Brasil para ministrar aulas na USP na condição de professor visitante. Sob o seu incentivo, viajou aos Estados Unidos em 1962, onde cursou pós-graduação em Análise Experimental do Comportamento/Psicologia Experimental na Columbia University, lá permanecendo até 1969.

Em sua formação pós-graduada, Maria Amelia foi aluna de ilustres mestres em Análise do Comportamento. Além do Professor Keller, orgulhava-se de ter sido orientada no doutorado pelo Professor William Nat Schoenfeld. Tal orgulho procedia, pois muito provavelmente tenha nascido desta convivência a sua capacidade de esmiuçar como ninguém um trabalho experimental, raciocinando a lógica de um experimento no contexto dos fatores que levam à pergunta de pesquisa, à metodologia utilizada, às interpretações levantadas. Particularmente, com o professor Keller, Maria Amelia adquiriu habilidades de programação de ensino. Em 1969, retornou ao Brasil e iniciou as suas atividades como docente da Universidade de São Paulo. Período difícil, em que não lhe fora concedido vínculo empregatício nos primeiros meses e, portanto, despendeu um grande esforço para se sustentar financeiramente.

Maria Amelia foi uma exímia e generosa professora. Ela trabalhava muito para as suas disciplinas, planejando cuidadosamente as suas aulas, uma a uma. Programadora de contingências, propiciava a seus alunos a experiência

1 Agradeço as contribuições da Profa. Deisy das Graças de Souza (UFSCar) a este relato.

2 Endereço: Universidade de São Paulo, Instituto de Psicologia, Av. Prof. Mello Moraes 1721, São Paulo, SP, Brasil 05508-030. E-mail: tomanari@usp.br concreta de passar por um processo muito intenso e veloz de aprendizagem, algo que ela nos repassava a partir da sua própria experiência:

A única maneira que posso descrever o que se passava comigo [no período em que estudou na Columbia University] é que, às vezes, assim, eu parava para me observar e me sentia crescendo, lembro-me nitidamente dessa sensação, de que o volume e a quantidade, a velocidade de aprendizagem era tão grande que dava para você perceber que estava mudando, que estava ampliando aquilo que você sabia falar, dizer, fazer. (Morais, 1999, p. 36)

Maria Amelia era uma formadora do pensamento crítico. Era uma formadora de atitudes científicas. De sua experiência com o ensino programado muito provavelmente derivou o fato de acreditar na capacidade de seus alunos, buscando tratar todos individual e igualmente no que diz respeito à capacidade de aprendizagem.

tenho muita necessidade, quase que uma compulsão, de equanimidade, ou seja, de tratar todo o mundo, realmente, por igual (em termos de possibilidade, em termos de avaliação, não). (...) todo trabalho feito por aluno é corrigido individualmente, minuciosamente anotado, ninguém entende minha letra, mas é para comentar e discutir depois com os alunos. (Morais, 1999, pp. 77-78)

Maria Amelia foi uma das pioneiras da Psicologia no Brasil, tendo ajudado a construí-la na forma como a conhecemos hoje. Ainda estudante, militou no processo de regulamentação da profissão de psicólogo em companhia da sua então professora Carolina Martuscelli Bori (1924-2004), com quem veio a fortalecer fortes laços de amizade e de companheirismo ao longo de toda a vida. Em sua trajetória acadêmica, a sua liderança foi marcante. Participou ativamente de sociedades científicas, em especial da Sociedade Brasileira de Psicologia, da qual foi secretária na primeira gestão (logo após a transformação da Sociedade de Psicologia de Ribeirão Preto em SBP) e à qual imprimiu estilo de organização. Contribuiu para a criação e a manutenção do programa de pós-graduação em Psicologia Experimental da Universidade de São Paulo. Montou, na USP, o primeiro laboratório de pesquisa em Análise Experimental do Comportamento do país. Deixou fortes marcas em diversos centros em que atuou pontualmente como professora visitante (UFBA e PUC-SP, por exemplo). Ao longo de uma extensa 
atuação em trabalhos de editoria e assessoria de publicações científicas nacionais e internacionais, Maria Amelia ensinou muitos de nós a publicar.

Em Análise do Comportamento, particularmente, Maria Amelia revelou a sua liderança ao longo de uma carreira em que se consolidou como uma indiscutível referência como pesquisadora que deixa um expressivo volume de publicações de impacto. Formou mais de 30 mestres e 30 doutores que hoje atuam em diversos centros de ensino e pesquisa do país. Deixou relevantes contribuições em aspectos teóricos e conceituais do Behaviorismo. Experimentalmente, lidou com processos comportamentais e de aprendizagem em linhas de pesquisa sobre controle aversivo, controle de estímulos (discriminações simples, discriminações condicionais, equivalência de estímulos), comportamento verbal, comportamento governado por regras. Realizou pesquisas básicas com animais e, desde a última década, passou a investigar, em humanos, processos comportamentais subjacentes à leitura recombinativa a partir de unidades mínimas. Para Maria Amelia, preocupação metodológica era uma constante: "em experimentação você precisa cobrir todos os detalhes" (Morais, 1999, p. 49), dizia ela. E, nesse tocante, contribuiu com técnicas de observação do comportamento, tendo produzido pesquisas, desenvolvido métodos, medidas, catálogos, livros (por exemplo, Matos \& Danna, 1999). Mais recentemente, atenta ao ensino de graduação, publicou um livro didático para o ensino de Análise Experimental do Comportamento (Matos \& Tomanari, 2002) que reflete a sua experiência acumulada no ensino de atividades de laboratório.

Pessoalmente, como amiga e colega de trabalho, era contagiante a erudição de Maria Amelia, muitas vezes revelada pelo seu impressionante interesse por outras culturas, em seus aspectos históricos e sociais. Ela possuía uma capacidade acurada, minuciosa, detalhista de observar o mundo, no qual se inclui o comportamento das pessoas. Era capaz de descrever e analisar comportamento com muita precisão, depreendendo implicações e antecipando fatos. Era igualmente impressionante a sua capacidade de se colocar sob a perspectiva de seu interlocutor - é verdade, muitas vezes com algum atraso, quando ela assim o reconhecia após ter sido tomada por algum grau da impulsividade, impaciência e força que trazia consigo. Força que, compreensivelmente, coadunava com a sua obsessão ao trabalho, ao trabalho de qualidade, que exigia de si e das pessoas à sua volta. Dizia ela: "cobro muito e cobro tanto quanto posso... não deixo nada ao acaso" (Morais, 1999, p. 79).

A ausência da Maria Amelia deixa um enorme vácuo para a Psicologia e para a Análise do Comportamento. Resta-nos, entretanto, importantes legados para nos confortar. Maria Amelia deixa contribuições científicas de primeira grandeza e, principalmente, deixa marcas permanentes aos que tiveram a oportunidade de se expor às contingências que se estabeleciam na convivência afetuosa com ela. Pessoalmente, guardo, honrado, cada uma das mudanças que ela promoveu em meu comportamento e que evoluem para admirá-la cada vez mais.

"Ela viajou para Birigüi para ficar, quem não terá saudades?” (Olavo Galvão, UFPA).

\section{Referências}

Matos, M. A. \& Danna, M. F. (1999). Ensinando observação: Uma introdução (6 ${ }^{\mathrm{a}}$ ed.). São Paulo: Edicon.

Matos, M. A. \& Tomanari, G. Y. (2002). A análise do comportamento no laboratório didático. São Paulo: Manole.

Morais, S. T. P. (1999). Professores universitários e psicólogos contam suas vidas. (Vol. IV, entrevista 29). Tese de doutorado, Universidade de São Paulo, São Paulo.

Recebido em 12.08.2005

Aceito em 15.08.2005 